Digitalizacja archiwalnych numerów czasopisma naukowego Analecta Cracoviensia 1-24 (1969-1992) i ich publikacja w otwartym dostępie - zadanie finansowane w ramach umowy 672/P-DUN/2017 ze środków Ministra Nauki i Szkolnictwa Wyższego przeznaczonych na działalność upowszechniającą naukę

\title{
KWALIFIKACJA TEOLOGICZNA WYZNANIA WIARY PAWEA VI
}

W uroczystość zamknięcia roku wiary, obchodzonej dnia 30 czerwca 1968 r., z okazji 1900 rocznicy męczeństwa świętych apostołów Piotra i Pawła, Ojciec św. Paweł VI odmówił przed bazyliką św. Piotra w Rzymie Uroczyste wyznanie wiary. ${ }^{1}$ Nie ulega wątpliwości, że Wyznaniu temu należy przypisać duże znaczenie. Zaznacza to sam Papież we wstępie, którym je zaopatrzył. ${ }^{2}$ Podobnie je oceniają również inne wypowiedzi. ${ }^{3}$ Stąd bliższe zbadanie wartości doktrynalnej papieskiego Credo, $\mathrm{i}$ to $\mathrm{w}$ oparciu głównie o analizę teologiczną tego wstępu, powinno zainteresować duszpasterzy, a zwłaszcza teologów. W artykule niniejszym podejmujemy to właśnie zadanie.

\section{I.}

Pełny tekst tytułu Pawłowego Credo brzmi następująco: U r o c z yste wyznanie wi ary (Sollemnis professio fidei) ${ }^{4}$. Należy od razu podkreślić, że tytuł ten jest najzupełniej słuszny. Swoją bowiem treścią,

1 Sollemnis professio fidei, AAS, 60 (1968) 433-445. Należy zaznaczyć, że ów oficjalny tekst łaciński nie pokrywa się zawsze z tekstem łacińskim opublikowanym w „L'Osservatore Romano”, 108 (1968, nr 149) 1-2, z dnia $1-2$ lipca.

" 2 AAS, 60 (1968) 433-445. Opuszczenie tego wstępu w „Tygodniku Powszechnym", 22 (1968, nr 41) 2, z dnia 13 października, nie wydaje się być właściwe.

3 ,C'era, perciô, un attesa nel popolo cristiano d'una parola autorevole che restituisse la certezza della fede. Questa parola autorevole è venuta dal Papa, ed ha constitutito uno dei momenti più alti del pontificatio di Paulo VI, "La Civiltà Cattolica", 119 (1968, t. 3) 3. - Por. „Nouvelle Revue Théologique”, 90 (1968) 982.

4 AAS, 60 (1968) 433 - Tytuł w „L'Osservatore Romano”, 108 (1968, nr 149) 1, z dnia 1-2 lipca, jest znacznie dłuższy: „Il Santo Padre Paulo VI conclude l'«Anno della fede» con ampia e solenne professione del nostro Credo da Lui pronunciata in nome e nella unità dell'intera Chiesa". 
jak i rodzajem literackim, papieski dokument przypomina dawniejsze symbole, tj. wylicza i przedstawia główne artykuły wiary. ${ }^{5}$

Posiada to również duże znaczenie dla rozpoznania jego wartości doktrynalnej, ponieważ treść i rolę nowego Credo należy oceniać w świetle już istniejących symboli wiary. Jak wiadomo były one, zwłaszcza w okresie patrystycznym, bardzo liczne. Powstanie swe zawdzięczały różnym okolicznościom, najczęściej wielkim herezjom. ${ }^{6}$ Pomimo różnorodnych początków i ujęć, zasadnicza ich treść jest jednakowa i bywa często wyrażana $\mathrm{w}$ identycznych słowach. ${ }^{7}$ Podając $\mathrm{w}$ formie skondensowanej główne prawdy wiary, symbole spełniały przede wszystkim funkcję reguły wiary (regula fidei). ${ }^{8}$ Tę rolę odgrywały one w Kościołach lokalnych, ${ }^{9}$ na synodach partykularnych ${ }^{10}$, oraz soborach powszechnych ${ }^{11}$, i to zarówno u katolików jak i u prawosławnych ${ }^{12}$. Tę samą

5 Daniélou I., Riflessioni sul „Credo del Popolo di Dio”, „La Civiltà Cattolica”, 119 (1968, t. 4) 231.

6 Lehmann K., Bedarf das Glaubensbekenntnis einer Neufassung?, w: Veraltetes Glaubensbekenntnis?, Regensburg 1968, 133-135.

7 Tamże, $139-141$.

$8 \mathrm{~W}$ ten sposób ujmuje rolę wyznań wiary sam Paweł VI w pierwszym komentarzu do swego Credo. „Una professione di fede non può essere che un riassunto, un "simbolo", come si dice nel linguaggio teologico tradizionale, una formula, una "regula fidei«, che contiene le principali verità della fede, in termini autorevoli, ma quando più possibile condensati ed abbreviati", "L'Osservatore Romano", 108 (1968, nr 151) 1, z dnia 4 lipca. Por. Fransen P., Glaubensbekenntnis. I. Geschichte und theol. Bedeutung, LThK, 4 (21960) 935-938. - Bardzo znane jest także zastosowanie wyznań wiary w liturgii, zwłaszcza liturgii chrztu i eucharystii oraz w prawie kościelnym. Tutaj jednak nie będziemy się nim bliżej zajmować. Por. Stenzel A., Glaubensbekenntnis. II. Liturgisch, LThK, 4 (21960) 938-939. -. Kaiser M., Professio fidei, LThK, 8 (21963) 784.

9 Np. Formula ,Fides Damasi” nuncupata, DS, 71-72; Symbolum ,Clemens Trinitas", DS, 73-74; Symbolum „Quinque” pseudo-Athanasianum, DS, 75-76 (DS = H. Denzinger - A. Schönmetzer, Enchiridion symbolorum, Herder ${ }^{34} 1967$ ).

10 Np. Conc. Toletanum XI, coeptum 7. Nov. 675: Symbolum, DS, 525-541; Conc. Toletanum XVI, coeptum 2 Maii 693: Symbolum, DS, 568-575; Conc. Remense (Reims), coeptum 21 Mart. 1148: Professio fidei, DS, 745.

11 Np. Conc. (oecum. I) Nicaenum I: 19. Jun. - 25. Aug. 325, DS, 125-126 (Symbolum Nicaenum); Conc. (oecum. II) Constantinopolitanum I: Maii - 30. Iul. 381, DS, 150 (Symbolum Constinopolitanum); Conc. (oecum IV) Chalcedonense: 8. Oct.-init. Nov. 451, DS, 300-303 (Symbolum Chalcedonense); Conc. (oecum. XII) Lateranense IV: 11-30. Nov. 1215, DS, 800-801 (Cap. 1. De fide catholica); Conc. (oecum. XIX) Tridentinum: 13. Dec. 1545 - 4. Dec. 1563, DS, 1862-1870 (Bulla iniunctum nobis).

12 „Libellus fidei Hormisdae papae” C'polim missus 11. Aug. 515, DS, 363-365 (Professio fidei contra errores christologicos); Michaelis imp. Ep. ad Gregorium pp., DS, 851-861 (Professio fidei Michaelis Paleologi imperatoris); Bulla unionis Graecorum „Laetentur caeli", 6. Iul. 1439, DS, 1300-1308 (Decretum pro Graecis); Bulla unionis Armeniorum „Exultate Deo”, 22. Nov. 1439, DS, 1310-1328 (Decretum pro Armeniis); Bulla unionis Coptorum Aethiopumque "Cantate Domino", 4. Febr. 1442 (1441 stilo Florent.), DS, 1330-1353 (Decretum pro Jacobitis); Decr. pro Ecclesia Graeco-Russiaca, a. 1575, DS, 1985-1987 (Professio fidei Graecis prae-scripta); Const. ,Nuper ad nos", 16. Mart. 1743, DS, 2525-2540 (Professio fidei Orientalibus praescripta). 
rolę przypisywało im również wielu papieży: Leon IX ${ }^{13}$, Innocenty III ${ }^{14}$, Aleksander VII ${ }^{15}$, Pius $X^{16}$. Innymi słowy, symbole wiary, zawierające mniejszy lub większy zestaw prawd wyznawanych w Kościele, służyły chrześcijanom do orientacji $\mathrm{w}$ doktrynie i stanowiły praktyczną i wiążącą normę dla ich świadomości religijnej.

Wybranie więc przez Pawła VI formy Credo, a nie encykliki, dla dokumentu o znaczeniu doktrynalnym wydaje się być celowe. Dzięki temu bowiem tekst nabral charakteru bardzo uroczystego. Ale nie to jest najważniejsze. Zgodnie $\mathrm{z}$ tradycją, encykliki zazwyczaj zawierają wyraźne aluzje do błędów, przeciw którym się zwracają. Credo pozwoliło na sformułowanie doktryny całkowicie pozytywne. Unikając anatem, przypomniało jedynie zasadniczą treść całej wiary. W ten sposób, zgodnie z duchem czasów dzisiejszych, umożliwia ono odróżnienie prawdy od błędów doktrynalnych i jasno stwierdza, że odnośnie depozytu wiary Kościół nie może poczynić żadnych ustępstw. ${ }^{17}$

Wybierając formę Credo dla swej doktrynalnej enuncjacji, Paweł VI osiągnął jeszcze inny cel, a mianowicie przypomniał aktualność tradycyjnych symboli wiary i w oparciu o ich autorytet wzmocnił także powage własnego Wyznania. Pomimo wprowadzenia, ,pewnej ilości objaśnień na czasie", co do istoty powtarza ono formułę nicejską. ${ }^{18}$ Tak jak symbol nicejski i wszystkie inne wielkie symbole wiary, Credo Pawłowe jest wyrazem nieprzerwanej, ciągle się rozwijającæj i postępującej naprzód pracy Kościoła nad zgłębianiem i autentycznym wyjaśnianiem Objawienia Bożego. Tak jak one także nie tylko przekazuje tradycję doktrynalną wiary, lecz ukazuje również organiczny jej rozwój. ${ }^{19}$

Wiadomo jeszcze, że teologowie podjęli ostatnio próby, aby opracować nowe wyznanie wiary, bardziej wychodzące naprzeciw współczesnej mentalności. Chodzi w nich o takie ujęcie istotnych prawd wiary, które, nie zarzucając objawionego depozytu, bardziej odpowiadałoby dzisiejszemu

13 Ep. „Congratulamur vehementer” ad Petrum patriarch. Antiochenum, 13 Apr. 1053, DS, 680-686 (Prafessio fidei).

14 Ep. „Eius exemplo” ad archiep. Terracon., 18. Dec. 1208, DS, 790-797 (Professio fidei Waldensibus praescripta).

15 Const. „Regiminis apostolici”, 15. Febr. 1665 (,,1664” st. cur.), DS. 2020 (Formularium submissionis Iansenistis propositum).

16 Litt. motu proprio „Sacrorum antistites", 1. Sept. 1910, DS, 3537-1550 (Iusiurandum contra errores modernismi).

17 Daniélou, Riflessioni sul „Credo del Popolo di Dio”, 235. „Plutôt que de présenter une liste d'erreurs, Paul VI a préféré affirmer des vérités aujourd'hui contestées ou estompées. A l'exposé solennel d'une encyclique, le Saint - Fère a préféré le langage vivant d'une profession de foi", Wenger A., Introduction, w: Paul VI, Profession de foi. Message aux prêtres, Paris 1968, 3.

18 ,...tamen formulam Nicaenam, quoad rerum summam, repetit, nonnulis adhibitis explicationibus, quas spirituales nostrae huius aetatis conditiones postulant: formulam dicimus immortalis traditionis Ecclesiae sanctae Dei", AAS, 60 (1968) 434. Por. Lehmann, Bedarf das Glaubensbekenntnis einer Neufassung?, 135-139.

19 Daniélou, Riflessioni sul „Credo del Popolo di Dio”, 232. 
człowiekowi.20 Credo Pawła VI stanowi dla tych wysiłków pomoc zasadniczą, zwłaszcza od strony treści; pokazuje bowiem, które prawdy wiary muszą się znaleźć w każdej kerygmie i każdej katechezie.

II.

W teologicznej analizie samej treści wstępu, który poprzedza Uroczyste wyznanie wiary, szczególnej uwagi wymaga to, co mówi tam $\mathrm{Pa}-$ pież na temat przyczyn, które doprowadziły do jego promulgacji i o zaangażowaniu weń swego najwyższego autorytetu nauczycielskiego. Obie te kwestie bowiem rzutują bardzo na stopień pewności teologicznej interesującego nas dokumentu.

1. Powody ogłoszenia Credo przez Pawła VI dają się odkryć bez większych trudności. Mają one swe źródło - najogólniej rzecz biorąc we współczesnym kryzysie wiary na świecie. Oczywiście nie jest to zjawisko całkowicie nowe. Człowiek miał zawsze, zależnie od epoki, w której żył, różnego rodzaju trudności z afirmacją Boga i perspektywami nadprzyrodzonymi własnej egzystnecji..21 Obecnie jednak, z różnych powodów, trudności te ujawniają się w proporcjach znacznie większych, niż poprzednio. ${ }^{22}$ Nie są to już tylko trudności na temat tego czy innego dogmatu. Chodzi w nich raczej o kryzys poznania w ogóle. ${ }^{23}$

W Kościele katolickim symptomy kryzysu doktrynalnego ujawniły się ze szczególną siłą po II soborze watykańskim. Urzędowo zasygnalizował je po raz pierwszy list Świętej Kongregacji nauki wiary do przewodniczących konferencji episkopatów. ${ }^{24}$ Mówi on o ,pojawieniu się dość licznych sentencji, które przekraczając beztrosko granice zwykłej opinii lub hipotezy, wydają się naruszać w pewnym stopniu sam dogmat i podstawy wiary". ${ }^{25}$ Wielu teologów bowiem, nie odróżniając dwóch odrębnych dziedzin, a mianowicie wiary i poszukiwań naukowych, zaczęło poważnie swymi poglądami zagrażać wierze, usiłując je przedsta-

20 Rahner K., Die Forderung nach einer "Kurzformel» des christlichen Glaubens, „Concilium”, 3 (1967) 203-207. Varillon F., Un abrégé de la foi catholique, „Etudes”, 10 (1967) 3-27. - Interesujące refleksje na ten temat można zraleść w: Lehmann, Bedarf das Glaubensbekenntnis einer Neufassung?, 153-174.

21 Aubert R., Le problème de l'acte de foi, Louvain ${ }^{3} 1958$.

22 Bardzo interesująca $w$ tym względzie jest praca zbiorowa wydana przez Girardi S. - Six S. F., L'athéisme dans la vie et la culture contemporaines, t. I, voll I, Paris 1967; t. I, vol. II, Paris 1968.

23 "Questo problema non è caratterizzato soltanto da difficoltà riguardanti questo o quel domma, ma da una crisi dell'intelligenza", Daniélou, Riflessioni sul „Credo del Popolo di Dio”, 229. Por. Thurian M., La foi en crise, Taizé 1968.

24 Epistula, AAS, 58 (1966) 659-661.

25, ,...constat de non paucis sententiis quae limites simplicis opinionis vel hypotheseos facile praetergredientes ipsum dogma et fidei fundamenta aliquatenus afficere videntur", Tamże, 660 . 
wiać jako naukę Kościoła. ${ }^{26}$ Szczególnie uwidacznia się to $\mathrm{w}$ fałszywej interpretacji dokumentów soborowych. ${ }^{27}$

Już uroczystości związane $\mathrm{z}$ rokiem wiary (1967/1968) starały się wyjść naprzeciw tej sytuacji. W intencjach Ojca św. głównym ich zadaniem było pogłębienie chrześcijaskiej cnoty wiary zarówno u wiernych, jak i u hierarchii. ${ }^{28}$

Włączenie w program I synodu biskupów problematyki traktującej o współczesnych niebezpiecznych błędach i o ateiźmie było dalszym krokiem w tym kierunku. ${ }^{29}$ Dyskusja synodalna wskazała na bardzo szeroki ich wachlarz. Zasięgiem swym obejmują one podstawy wiary ${ }^{30}$, chrystologię ${ }^{31}$, eklezjologię ${ }^{32}$, antropologię ${ }^{33}$, teologię moralną ${ }^{34}$, kontrolę urodzeń ${ }^{35}$, sakramenty św. ${ }^{36}$, ekumenizm ${ }^{37}$. Wobec tego biskupi ,uznali za rzecz słuszną, aby Stolica Apostolska, po wysłuchaniu konferencji episkopatów, opracowała pozytywną deklarację pastoralną na temat zagadnień mających związek z dzisiejszą problematyką doktrynalną, dla zapewnienia ludowi Bożemu pewnego przewodnika we wierze". ${ }^{38}$ Wielu $\mathrm{z}$ nich domagało się wprost, aby to był symbol albo reguła wiary. ${ }^{39}$ Głosy te uprawniają bez wątpienia do wniosku, że Pawłowe Wyznanie

26 Daniélou, Riflessioni sul "Credo del Popolo di Dio", 234.

27 „De ce renouvellement, le dernier concile a tracé le programme. Chacun s'en réclame (ou s'en réclamait), mais en des sens divers. En fait, il est peu connu, peu suivi. Plusieurs de ceux qui prétendaient être les seuls à le prendre aux sérieux, aujourd'hui le dédaignent. Dès la première heure, une interprétation déformante avaiit commencé d'en être répadue", Lubac $\mathrm{H}$. de, L'Église dans la. crise actuelle, „Nouvelle Revue théologique”, 101 (1969) 587. Por. tamże, 580-596.

28 Por. Audiencja ogólna z dnia 1 marca 1967 r. w: ,Insegnamenti di Paulo VI", 5 (1967) 695-697; Audiencja konferencji episkopatu włoskiego z dnia 4 kwietnia 1967, w: AAS, 49 (1967) 408-409.

29 Synod biskupów zajął się tą problematyką w dniach od 4 do 10 i od 26 do 27 października 1967. Por. Caprile G., Il Sinodo dei vescovi. Prima assemblea generale (29.IX -29.X.1967), Roma 1968, 141-236. - Laurentin R., Le premier Synode. Histoire et bilan, Paris 1968, 92-129. - W dalszych przypisach cytujemy monografię G. Caprile, ponieważ uważa się ją za najlepszą z dotychczasowych, które napisano na temat I synodu biskupów.

30 Caprile, Il Sinodo dei vescovi, 147; 155; 188; 195; 198; 201; 204; $217 ; 223$; $234 ; 623$.

31 Tamże, $147-148 ; 155-156 ; 170 ; 175 ; 176 ; 178 ; 183 ; 188 ; 189 ; 195 ; 204$, $207 ; 228 ; 623$.

32 Tjamże, $148 ; 156 ; 175 ; 188 ; 195 ; 205 ; 217 ; 228 ; 623$.

33 Tamże, $148 ; 156 ; 170 ; 175 ; 195 ; 196 ; 227 ; 228 ; 624 ; 637-638$.

34 Tamże, $150 ; 151 ; 157 ; 170 ; 175 ; 176 ; 178 ; 183 ; 188 ; 195 ; 198 ; 206 ; 228 ; 624$.

35 Tamże, $157 ; 170$.

36 Tamże, $151 ; 152 ; 178 ; 624$.

37 Tamże, 624.

38 „Ritengono opportuno i Padri che la Sede Apostolica, udite le Conferenze Episcopali, elabori una dichiarazione positiva e pastorale sui problemi riguardanti l'odierna "problematica" dottrinale, per una guida sicura della fede del popolo di Dio?", Tamże, 232. — Jest to cytat z relacji opracowanej przez specjalną komisję synodalną do spraw doktrynalnych pod przewodnictwem kard. F. Śepera. O działalności tej komisji zob. tamże, $184 ; 192 ; 196 ; 203 ; 206 ; 221 ; 224 ; 226 ; 227-234$; $235 ; 249 ; 257 ; 261 ; 506 ; 561 ; 564 ; 591$. 
wiary jest właśnie ową deklaracją postulowaną przez I synod i mającą wyjść naprzeciw kryzysowi doktryny w Kościele.40

W międzyczasie pojawiła się sprawa Nowego Katechizmu holenderskiego, która nabrała ogólno kościelnego rozgłosu. ${ }^{41}$ Specjalna komisja kardynalska, w skład której wchodzili kardynałowie: J. Frings, S. Lefebvre, W. Jaeger, E. Florit, M. Browne, Ch. Journet, powołana przez Pawła VI do zbadania ortodoksyjności tego katechizmu, zgłosiła pod jego adresem szereg zastrzeżeń i poprawek doktrynalnych. ${ }^{42}$ Ponieważ. spora ilość pominiętych lub błędnie przedstawionych artykułów wiary w katechiźmie holenderskim została wprowadzona w poprawnym sformułowaniu do Pawłowego Credo, niektórzy autorowie przypuszczają, że stanowi ono odpowiedź papieską na jego oryginalne, lecz czasem nieortodoksyjne sugestie doktrynalne. ${ }^{43}$

Sam Paweł VI widzi również w swym Wyznaniu odpowiedź na aktualne trudności w wierze. Podkreśla bowiem z naciskiem, że wygłaszając swe Credo, miał na myśli niepokój, który ogarnia wiele środowisk nowoczesnych w kwestiach wiary. Często zaprzecza się całkowicie istnieniu wielu prawd albo się je zniekształca. Pasja nowości doprowadza niektórych katolików nawet do tego, ża adaptacja Objawienia w zmienionych warunkach jest przeprowadzana ze szkodą dla depozytu wiary. Szczególniej zagrożona jest obiektywność poznania ludzkiego i hermeneutyka, czyli sposób interpretacji ksiąg świętych.44

39 Tamże, $172 ; 178 ; 181 ; 185 ; 187 ; 193 ; 196 ; 209 ; 211 ; 213 ; 221 ; 233 ; 625 ; 637$.

40 "Il documento sembra rispondere alla richiesta avanzata da molti Padri durante il Sinodo", Tamże, 638. - Nie wiadomo jednak, czy ogłaszając Credo Paweł VI całkowicie spełnił żądanie biskupów wyrażone na synodzie i czy nie planuje jeszcze innego dokumentu o charakterze doktrynalnym, który by zadość czynił ich żądaniom. Por. Zizola G., Loin de toute "passion» pour «le changement et la nouveaute", "Informations catholiques internationales", 316 (1968) 10, z dnia 15 lipca.

41 A New Catechism. Catholic Faith for Adults, London-New York 1967. Tytuł oryginalny w języku holenderskim brzmi: „De nieuwe Katechismus”. Przekładu angielskiego dokonał $\mathrm{K}$. Smyth. Istnieją również inne tłumaczenia. Między innymi na język niemiecki, francuski i włoski.

42 Commissio Cardinalitia de "Novo Catechismo» («De nieuwe Katechismus»), AAS, 60 (1968) 695-691. - Por. Il Dossier del catechismo olandese, Verona 1968. Kuiper V. M., „Hauptsünden” des holländischen Neuen Katechismus, Zurüch 1967.

43 Publicada últimamente de una manera oficial la declaración sobre el «Neuvo Catecismo» holandés, pronunciada por la Comisión Cardenalicia instituida para examinarlo, se podrá combrodar que buena parte de los puntos que, a juicio de la Comisión, requieren explicación o complemento, han sido introducidos con la recta fórmula doctrinal en la Profesión de fe que estudiamos", Nicolau M., La reciente Profesión de fe de Pablo VI, „Salmanticensis”, 16 (1969) 69. - Jednak opinia, że Credo Pawła VI stanowi zestaw głównych zarzutów poczynionych przez teologów rzymskich katechizmowi holenderskiemu, wydaje się być przesadą. Por. Zizola Loin de toute "passion» pour "le changement et la nouveauté", 10.

44 "Qui quidem affectionem mundi sese penitus mutantis non effugerunt, in quo tot veritates vel prorsus negantur, vel in controversiam vocantur... Sed simul maximopere cavendum est ne, dum necessarium investigandi officium usurpatur, christianae doctrinae veritates labefactentur. Quod si fiat - videmusque, pro dolor, 
W tym kontekście Uroczyste wyznanie pozytywnie konfrontuje zdrową naukę z błędnymi innowacjami, opowiada się za tradycyjną doktryną przeciwko niebezpiecznym tendencjom, stanowi autorytatywną odpowiedź najwyższego urzędu nauczycielskiego Kościoła na problemy doktrynalne epoki. Sam Paweł VI mówi, że stara się w nim „odpowiedzić we właściwy sposób na potrzebę światła odczuwaną przez wiele dusz wiernych i przez wszystkich tych w świecie, którzy obojętnie, do jakiej rodziny duchowej należą, poszukują prawdy". ${ }^{4}$

Z teologicznego punktu widzenia, przytoczone okoliczności są niezwykle ważne. ${ }^{46}$ Mówią one, że Papież chce przypomnieć Kościołowi naukę wiary. W obliczu dezorientacji licznych chrześcijan, pytających, w co mają wierzyć, podał prawdy pewne, poza dyskusją, należące do depozytu wiary. Inaczej mówiąc, proklamował uroczyście wiarę całego Kościoła. ${ }^{47}$

Okoliczności powyższe, $\mathrm{z}$ tych właśnie względów, rzutują również na wartość doktrynalną Pawłowego Credo. We współczesnych, zmienionych warunkach, podaje ono doktrynę powszechnie przyjętą i obowiązującą w Kościele katolickim. Doktryny tej nie wolno porzucać, ponieważ posiada ona moc wiążącą świadomość religijną i życie wiernych.

2. Jak wiadomo nie wszystkie prawdy i zasady moralne uznane w Kościele cieszą się jednakową pewnością. Główną przyczyną tego stanu rzeczy jest fakt, że różny jest ich stosunek do Objawienia Bożego. I tak, jedne $\mathrm{z}$ nich znajdują się tam wyraźnie, inne znowu wynikają zeń z mniejszą lub wiekszą oczywistością. W zależności od rodzaju wzajemnych powiązań teologowie wyróżniają różne typy zadań objawionych. ${ }^{48}$

hodie id reipsa fieri - perturbationem et dubitationem fidelibus multorum animis afferat.

Ad hanc rem quod spectat, summi est momenti animadvertere, praeter id quod observabile est, scientiarumque ope recognitum, intellegentiam a Deo nobis datam $i d$ quod est attingere posse, non vero tantummodo significationes subiectivas structurarum, quas vocant, et evolutionis humanae conscientiae. Ceterum recolendum est, illud ad interpretationem seu ad hermeneuma pertinere, ut, verbo, quod pronuntiatum est, observato, intellegere et discernere studeamus sensum textui cuidam subiectum, non vero hunc sensum ad coniecturae arbitratum quodammodo novare”, AAS, 60 (1968) 434-435. - Por. Daniélou, Riflessioni sul „Credo del Popolo di Dio", 229-230.

45 „Hanc autem Nostram fidei professionem satis et expletam et expressam esse volumus, ut apta ratione necessitati luminis satisfaciamus, qua tot fideles homines premuntur, iique omnes qui in mundo - ad quemcumque spiritualem coetum pertinent - Veritatem conquirunt", AAS, 60 (1968) 435.

${ }_{46}$ Por. Różycki I. ks., Dogmatyka, t. I, księga I: Metodologia teologii dogmatycznej. Kraków 1947, nn. 397-398.

47 Wenger A., Upsal. Le défi du siècle aux Églises, Paris 1968, 263-268. Por. „La Civiltà Cattolica”, 119 (1968, t. 3) 3. - Daniélou, Riflessioni sul „Credo del Popolo di Dio", 234.

48 Ks. Różycki, Dogmatyka, nn. 66, 68, 129, 130, 134, 135 (zdania objawione istotnie); 105-107 (równoznacznie); 103, 108, 127, 129, 130, 135, 140 (równoważnie); 63, 102, 109, 142 (zasadowo); 68 (bezpośrednio); 68, 140 (pośrednio). 
W interpretacji Objawienia niezmiernie ważna rola przypada nauczycielskiemu urzędowi Kościoła. Urząd ten ma bowiem prawo i obowiązek wydawać sądy o wielu sprawach związanych z Objawieniem..$^{49}$ Przede wszystkim rozstrzyga on, co jest objawione, a co nie. Następnie wyciąga wnioski z Objawienia i precyzuje, które twierdzenia są z nim nierozerwalnie złączone. Wreszcie może się wypowiedzieć na temat istniejących relacji pomiędy Objawieniem i naturalnym poznaniem. ${ }^{50} \mathrm{~W}$ istocie swej jest to rola służebna, ponieważ urząd nauczycielski nie jest ponad słowem Bożym, lecz naucza tylko tego, co zostało przekazane Objawieniem.51

Należy jednak podkreślić tutaj, że istnieją różne formy i stopnie zaangażowania się ze strony nauczycielskiego urzędu Kościoła w wykład wiary i moralności. Z jednej strony mamy definicje dogmatyczne, czyli orzeczenia, że dane, ściśle sprecyzowane, tezy są przez Boga objawione i stanowią konieczny przedmiot wiary. Na drugim krańcu znajdują się opinie teologiczne słabo uzasadnione i zaledwie tolerowane. Pomiędzy tymi biegunami przedstawiającymi najwyższy i najniższy stopień zaangażowania urzędu nauczycielskiego w autentyczny wykład Objawienia, istnieje jeszcze cała gama stopni pośrednich. ${ }^{52}$ Przy ustalaniu wartości doktrynalnej jakiegoś twierdzenia teologicznego powinno się więc bliżej zbadać, o który $\mathrm{z}$ nich chodzi $\mathrm{w}$ danym wypadku.

Postarajmy się teraz odpowiedzieć na pytanie, jak przedstawia się zaangażowanie autorytetu nauczycielskiego Ojca św. Pawła VI w odniesieniu do omawianego Wyznania wiary. Będzie to niewątpliwie decydujący krok na drodze do ustalenia jego kwalifikacji teologicznej ze względu na prymat, który zapewnia papieżowi jedyną w swoim rodzaju pozycję w Kościele. Jako biskup rzymski jest papież w urzędzie następcą św. Piotra, zastępcą Chrystusa, głową całego Kościoła, ojcem i nauczycielem wszystkich chrześcijan, z pełnią władzy pasterza i rządcy nad całym Kościołem. ${ }^{53}$ Będąc najwyższym nauczycielem nieomylnego

49 Pius IX, Ep. „Gravissimas inter” ad archiep. Monaco-Frising., 11. Dec. 1862, DS, 2861. - Conc. (oecum. XX) Vaticanum I, Constitutio dogmatica „Dei Filius" de fide catholica, DS, 3018. - Pius XII, Litt. encycl. „Humani generis", 12. Aug. 1950, AAS, 42 (1950) 568. - Conc. (Oecum. XXI) Vaticanum II, Constitutio dogmatica "Dei verbum" de divina Revelatione, w: Constitutiones. Decreta. Declarationes, Typis Polyglottis Vaticanis 1966, 431-432.

50 Kolping A., Qualificationen, LThk, 8 (21963) 916.

51 "Quod quidem Magisterium non supra verbum Dei est, sed eidem ministrat, docens nonnisi quod traditum est", Constitutio dogmatica "Dei verbum" de divina Revelatione, w: Constitutiones. Decreta. Declarationes, 432.

52 A. Kolping wymienia ich jeszcze sześć: „An den Glauben grenzt” (fidei proximum); „(Bloss) Kirchlichen Glaubens" (de fide ecclesiastica); ,Theologisch sicher" (theologice certum); „Allgemein vertretene These” (sententia communis); „Fromme Meinung" (sententia pia); ,Vertretbare Meinung” (sententia probabilis), Qualifikationen, 917-918, - Ks. Różycki, Dogmatyka, nn. 55, 176-180: 285-394.

53 Conc. (oecum. XVII) Florentinum, Bulla unionis Graecorum ,Laetentur caeli", 6. Iul. 1439, DS, 1307. - Vaticanum I, Constitutio dogmatica I "Pastor aeternus" de Ecclesia Christi, DS, 3059. 
we wierze Kościoła, cieszy się przywilejem nieomylności gdy przemawia ex cathedra. Definicje jego są wtedy nieodwołalne same przez się, a nie za zgodą Kościoła. ${ }^{54}$ Wszystko zatem, co powiada na temat zaangażowania swego autorytetu $\mathrm{w}$ jakiś dokument kościelny ma istotne znaczenie dla jego oceny doktrynalnej.

Zapewne Credo $\mathrm{Paw}$ a VI nie jest definicją dogmatyczną w ścisłym znaczeniu słowa. Jest tak dlatego, ponieważ wyraźnie nie chce on, aby dokument jego był definicją dogmatyczna. ${ }^{55} \mathrm{Czy}$ w takim razie zaliczyć je trzeba do papieskiegonauczania zwyczajnego? I owszem ${ }^{56}$, ale w formie osobliwie uroczystej (sollemnius verbum), spełniającej wiele warunków wymaganych do definitywnych rozstrzygnięć dogmatycznych ${ }^{57}$. Inaczej mówiąc, zajmuje ono szczególną, sobie właściwą pozycję w papieskim naczyniu zwyczajny m. ${ }^{58}$

Fakt, że Pawłowe Wyznanie wiary realizuje - poza intencją definiowania - inne warunki konieczne do orzeczeń dogmatycznych ex cathedra należy szczególniej uwypuklić, ponieważ potwierdza on naszą tezę o jego wyjątkowym znaczeniu doktrynalnym. Autorzy analizujący tekst definicji I soboru watykańskiego, proklamującej dogmat o nieo-

54 „Romanum Pontificem, cum ex cathedra loquitur, id est, cum omnium Christianorum pastoris et doctoris munere fungens pro suprema sua Apostolica auctoritate doctrinam de fide vel moribus ab universa Ecclesia tenendam definit, per assistentiam divinam ipsi in beato Petro promissam, ea infallibilitate pollere, qua divinus Redemptor Ecclesiam suam in definienda doctrina de fide vel moribus instructam esse voluit; ideoque eiusmodi Romani Pontificis definitiones ex sese, non autem ex consensu Ecclesiae, irreformabiles esse", Vaticanum I, Constitutio dogmatica I „Pastor aeternus” de Ecclesia Christi, DS, 3074. - Por. Ks. Różycki, Dogmatyka, nn. 369-370.

55 ,...quae, quamvis deflinitio dogmatica vere proprieque non nominanda", AAS, 60 (1968) 434.

56 „No se trata, por consiguinte, de una definición ex cathedra; no es un acto de magisterio extraordinario; pero si un acto de magisterio ordinario, que en el magisterio pontificio es el magisterio que se contradistingue del magisterio ex cathedra, que es perentorio y, por si mismo, definitivo e infalible", Nicolau La reciente Profesión de fe de Pablo VI, 70.

57 „Cum profecto non ignoremus homines verba expectare Christi Vicarii, propterea sermonibus et homiliis, quas Nobis persaepe habere placet, eorum expectationem explemus. Sed hodierno die opportunitas Nobis offertur sollemnius verbum proferendi", AAS, 60 (1968) 435.

58 Ks. H. Bogarki wyliczając ,akty formalne, których autorem jest sam $\mathrm{Pa}-$ pież", w jakich wyraża się nauczanie zwyozajne Stolicy Apostolskiej, nie wzmiankuje formy Credo, Posłuszeństwo należne papieskiemu nauczaniu zwyczajnemu, „Roczniki teologiczno-kanoniczne”, 9 (1962, z. 2) 9. Wydaje się jednak, że do wymienionych aktów formalnych papieży, będących różnymi formami ich nauczania zwyczajnego, należy zaliczyć także formę Credo, którą ks. Bogacki pominął, chyba ze względu na rzadkość występowania. 
mylności papieskiej, wymieniają cztery takie warunki.59 Otóż wszystkie one dają się odkryć w Pawłowym Credo.

a. Papież przemawiając ex cathedra musi spełniać urząd pasterza i nauczyciela wszystkich chrześcijan (omnium Christianorum pastor et doctor). Wiadomą jest rzeczą, że posiada i inne funkcje. Może występować np. jako osoba prywatna, teolog, biskup Rzymu, prymas Włoch, patriarcha zachodu. ${ }^{60}$ Otóż nie ulega wątpliwości, że w Credo występuje on w pierwszej, naczelnej swej funkcji: pasterza i nauczyciela wszystkich ochrzczonych. Stwierdza to własnymi słowami: „Jak kiedyś w Cezarei Filipowej Piotr, w imieniu dwunastu apostołów, prawdziwie wyznał niezależnie od opinii ludzkiej Chrystusa Synem Boga żywego, tak dzisiaj zabiera głos pokorny jego następca, pasterz Kościoła powszechnego w imieniu całego ludu Bożego". ${ }^{61}$

b. Dalej przy orzekaniu ex cathedra, papież angażuje w najwyższym stopniu swój apostolski autorytet, tj. ten, który wyłącznie jemu samemu, następcy Piotra przysługuje (pro suprema sua Apostolica auctoritate). Co więcej, papież powinien też dać do zrozumienia, że działa właśnie w oparciu o tę najwyżsą apostolską władzę. ${ }^{62}$ Czy w Credo to czyni? Co do tego, nie może być żadnej wątpliwości. „Jeżeli idzie o nas, sądzimy przeto - stwierdza Paweł VI - że mamy obowiązek spelnić mandat przez Chrystusa powierzony Piotrowi, którego jesteśmy ostatnim co do zasługi zastępcą, a mianowicie we wierze utwierdzać braci ( $€ \mathrm{k} 22$, 32). Dlatego, chociaż świadomi jesteśmy naszej słabości, to jednak z całą mocą, którą czerpiemy z mandatu nam przyznanego, przystępujemy do wyznania wiary". ${ }^{63}$

c. Przedmiotem papieskiej definicji dogmatycznej może być wyłącznie nauka wiary lub moralności (doctrina de fide vel moribus). Nie wchodzą zatem $w$ jej zakres np. kwestie dyscyplinarne i administracyjne. ${ }^{64} \mathrm{I}$ o tym warunku trzeba powiedzieć, że Credo Pawłowe spełnia go całkowicie. Jest ono przecież wyznaniem wiary, które chce oddać „mocne świadectwo Prawdzie Bożej”. ${ }^{65}$ Zresztą dokument w formie Credo

59 Thils G., L'infaillibilité du Pape selon la définition de Vatican I, Louvain 1968, 165-171. Por. tamże, 172-176 (Les autres conditions).

60 Tamże, 165.

61 „Atque quemadmodum olim Caesareae Philippi Simon Petrus, duodecim Apostolorum nomine, praeter hominum opiniones, vere Christum Dei viventis Filium professus est, ita hodie tenuis eius Successor, universaeque Ecclesiae Pastor, nomine totius populi Dei, vocem suam intendit", AAS, (1968) 435.

62 Thils, L’infaillibilité du Pape selon la définition de Vatican I, 166-167.

63 „Porro Nostrarum esse partium existimamus mandatum conficere a Christo delatum Petro, cuius Nos, licet meritis longe inferiores, successores sumus: ut nempe in fide confirmemus fratres. Quam ob rem, etsi exiguitatis Nostrae conscii sumus, maxima tamen animi vi, quam a mandato Nobis tradito ducimus, professionem fidei facturi sumus", AAS, 60 (1968) 434.

64 Thils, L'infaillibilité du Pape selon la définition de Vatican I, 167-169.

65 „...f firmissimum testimonium divinae Veritati”, AAS, 60 (1968) 435. 
ma zawsze za przedmiot właściwy kwestie wiary lub moralności. Lektura tekstu potwierdza to $\mathrm{w}$ pełni.

d. Wreszcie papieska definicja dogmatyczna może odnosić się tylko do tej doktryny, która ma moc wiążącą w całym Kościele (ab universa Ecclesia tenenda). Innymi słowy, konieczne jest, aby papież zobowiązał w niej do wiary i nadał jej charakter wiążący w odniesieniu nie do poszczególnych jednostek, społeczności religijnych, czy Kościołów lokalnych, ale w stosunku do wszystkich wiernych na całym świecie. Bez tego nie ma po prostu intencji orzekania nieomylnie. ${ }^{66} \mathrm{I}$ pod tym względem używa Paweł VI formuł niedwuznacznych. W jego Credo chodzi o „wiarę teologiczną, na której wspiera się życie Ciała Mistycznego". ${ }^{67}$ O prawdę, „która na to jest powierzona Kościołowi, aby ten głosił ją wszystkim narodom." 68 Jego ustami wyznaje ją cały Kościół, ponieważ przemawia on ,w imieniu wszystkich świętych pasterzy i wiernych i w pełnej łączności z braćmi i synami umiłowanymi". ${ }^{69}$ Nauka Credo nosi więc znamię powszechnej obowiązywalności.

Do tych uwag należy jeszcze dorzucić dwa elementy, zawarte we wstępie poprzedzającym papieskie wyznanie wiary. Są nimi: wzmianka o asystencji Ducha św. i uroczysta formuła wprowadzająca. Akcentując bardzo jego wysoką wartość doktrynalną, nakazują one również widzieć w nim dokument o większym znaczeniu wśród zwyczajnych form papieskiego nauczania.

Swą nieomylność w nauczaniu wiary, a zwłaszcza przy definitywnych rozstrzygnięciach ex cathedra zawdzięczają papieże Bogu, Prawdzie bezwzględnej. Nie mają jej zatem od siebie. Po prostu jest ona darem Bożym. Nie jest to jednak inspiracja na wzór tej, jaką cieszyli się autorzy natchnieni Pisma św., ani nowe Objawienie, uzupełnienie tego, które skończyło się z ostatnim z apostołów. Jest to po prostu specjalna pomoc Boża (assistentia divina). Teologowie nazywają ją chętnie asystencją Ducha Św. Towarzyszy ona bez przerwy całemu Kościołowi i dopomaga urzędowi nauczycielskiemu w autentycznym, bezbłędnym wykładzie Objawienia. ${ }^{70}$ Papieże cieszą się nią zawsze a w szczególności $\mathrm{w}$ momencie definiowania ex cathedra. Przyczyną sprawczą ich nieo-

66 Thils, L'infaillibilité du Pape selon la définition de Vatican I, 169-171.

67 ".... confidimus... et theologicae fidei, in qua Corporis mystici vita nititur", AAS, 60 (1968) 435 .

68 "...quae ideo Ecclesiae est credita, ut eam omnibus gentibus nuntiet", Tamże, 435 .

$69, \ldots$ nomine omnium sacrorum Pastorum et christifidelium, plenaque vobiscum, Fratres ac Filii dilectissimi, communione", Tamże, 436. - Bardzo wymowny w tym względzie jest tytuł, którym „L'Osservatore Romano”, 108 (1968, nr 149) 1, z dnia 1-2 lipca zaopatrzyło tekst Pawłowego wyznania wiary. Por. przyp. 4.

70 Thils, L'infaillibilité du Pape selon la définition de Vatican I, 112-128.

71 Colombo C., La professione di fede del popolo di Dio", "La Rivista del Clero italiano", 49 (1968) 515. 
mylności jest wówczas Bóg, Duch Ŝw. ${ }^{71}$ Stąd należy zauważyć, że Paweł VI wygłaszając Credo wspomina asystencję Ducha Św. „A nade wszystko pokładamy nadzieję w Duchu Św." 72 Fakt ten ma dużą wymowę doktrynalną, ponieważ świadczy, że prawdę jego nauki pragnął oprzeć nie na sobie, ale na Bogu, źródle i dawcy wszelkiej nieomylnej prawdy.

Jeszcze inny fakt ma dla doktryny Credo niemałe znaczenie, a mianowicie uroczysta formuła wprowadzająca. Jak wiadomo żadna forma zewnętrzna nie jest nałożona orzeczeniom ex cathedra. Oznacza to, że nie zakładają one żadnej określonej formy zewnętrznej. Mogą zatem znaleźć pełną realizację również $\mathrm{w}$ aktach nieuroczystych, zwykłych..$^{75}$ Niemniej jednak dotychczasowe definicje dogmatyczne miały charakter bardzo uroczysty. Swój najpełniejszy wyraz znajdywał on w formule wprowadzającej lub kończącej właściwe orzeczenie dogmatyczne. Otóż Pawłowe Credo i pod tym względem je przypomina. Końcowy akapit wstępu, stanowiący bezpośrednie wprowadzenie do jego tekstu, jest bardzo uroczysty. Tak swoim stylem, jak i treścią przypomina analogiczne formuły z bulli Piusa IX „Ineffabilis Deus” 74 i z konstytucji dogmatycznej Piusa XII „Munificentissimus Deus",75 czy dokumentów II soboru watykańskiego. ${ }^{76}$ A oto jego treść: „Na cześć więc wszechmocnego Boga i Pana naszego Jezusa Chrystusa, ufając w pomoc Najświętszej Dziewicy Maryi i świętych apostołów Piotra i Pawła, na pożytek i wzrost Kościoła, w imieniu wszystkich pasterzy i wszystkich wiernych, składamy obecnie to wyznanie wiary w pełnej łączności duchowej z wami wszystkimi drodzy bracia i synowie". ${ }^{77}$

72 „Attamen ante omnia Spiritui Sancto firmissime confidimus”, AAS, 30 (1968) 435 .

13 Thils, L'infaillibilité du Pape selon la définition de Vatican I, 217.

$74, \ldots .$. Ad honorem sanctae et individuae Trinitatis, ad decus et ornamentum Virginis Deiparae, ad exaltationem fidei catholicae et christianae religionis augmentum, auctoritiate Domini nostri Jesu Christi, beatorum Apostolorum Petri et Pauli ac Nostra declaramus, pronuntiamus et definimus, doctrinam, quae tenet...", Pius IX, Bulla „Ineffabilis Deus”, 8. Dec. 1954, DS, 2803.

75 „Quapropter ... ad Omnipotentis Dei gloriam, qui peculiarem benevolentiam suam Mariae Virgini dilargitus est, ad sui Filii honorem, immortalis saeculornm Regis ac peccati mortisque victoris, ad eiusdem augustae Matris augendam gloriam et ad totius Ecclesiae gaudium exultationemque, auctoritate Domini Nostri Jesu Christi, Beatorum Apostolorum Petri et Pauli ac Nostra pronuntiamus, declaramus et definimus divinitus revelatum dogma esse:...”, Pius XII, Const. Ap. „Munificentissimus Deus", 1. Nov. 1950, AAS, 42 (1950) 770.

76 Constitutiones. Decreta. Declarationes, 62, 88-89, 206, 239-240, 274, 321, $352-353,384,408,418,446-447,508,532,615,678,834-835$. Zwraca uwage fakt, że wszystkie dokumenty soboru watykańskiego II mają jedną i tę samą formulę końcową.

77 „Ad gloriam igitur Omnipotentis Dei et Domini nostri Jesu Christi, fiducia in auxilio Sanctissimae Virginis Mariae et beatorum Petri et Pauli Apostolorum collata, ad utilitatem spiritualemque progessionem Ecclesiae, nomine omnium sacrorum Pastorum et christifidelium, plenaque vobiscum, Fratres ac Filii dilectis- 
Wszystko to razem wzięte, ukazując bardzo wysoki stopień zaangażowania najwyższego autorytetu nauczycielskiego Papieża, potwierdza w pełni tezę o wyjątkowej pozycji Uroczystego wyznania wi a r y w kościelnym nauczaniu zwyczajnym. W z a s a d zie w Credo Pawła VI nie idzie o formułowanie nowych dogmató w. Nie zawiera też ononiczego, co nie byłoby w jakiś sposób uprzedniozawarte we wierze. Poprostu chce tylko, i to w sposób bardzo uroczysty, przypominający orzeczenia ex cathedra, reafirmować i ratyfikować tradycyjne prawdy, należace do depozytu wiary i będące jej stałym przedmiotem. ${ }^{78}$ W szczególności odnosi się to do tych prawd, które dzisiaj podlegają kontestacji i deformacji, np. istnienie aniołów, grzech pierworodny, wieczne dziewictwo N.M.P., eucharystia, czy nauka o królestwie Bożym.79

W większości swych twierdzeń Credo papieskie wyraża wspólną i powszechną wiarę całego Kościoła, prawdy formalnie objawione, częstokroć nawet nieomylnie zdefiniowane przez sobory powszechne i papieży. ${ }^{80}$ I tak znajdujemy $\mathrm{w}$ nim między innymi: dogmat soboru efeskiego o boskim macierzyństwie Maryji ${ }^{81}$, dogmat o unii bez pomieszania (sine confusione) natur boskiej i ludzkiej w jednej osobie Syna Bożego, zdefiniowany $\mathrm{w}$ Chalcedonie ${ }^{82}$, dogmaty o przeistoczeniu eucharystycznym ${ }^{83}$ i dziedziczeniu grzechu pierworodnego ${ }^{84}$, promulgowane przez sobór trydencki, dogmat o nieomylności papieskiej, dziedzictwo I soboru watykańskiego ${ }^{85}$, dwa dogmaty maryjne o niepokalanym poczęciu i wniebowzięciu Matki Bożej, ogłoszone przez Piusa IX ${ }^{86}$ i Piusa XII. ${ }^{87}$ Szczególną uwagę $\mathrm{w}$ tym względzie zwraca umieszczona w wielu

simi, communione, nunc hanc fidei professionem pronuntiamus", ASS, 60 (1968) 435-436. Twierdzenie Zizoli, że właśnie przez tę formułę Credo papieskie zyskało powagę doktrynalną bardzo bliską dokumentom ex cathedra wydaje się jednak za daleko posuwać w ocenie jej znaczenia, Loin de toute "passion" pour «le changement et la nouveauté», 10-11.

78 Daniélou, Riflessioni sul „Credo del Popolo di Dio”. 229.

79 „Sans être une définition dogmatique proprement dite, elle réaffirme les points de la doctrine traditionelle touchés par la contestation moderne", Wenger, Introduction, 8. - Por. tamże, 3-7 i „La Civilità Cattolica”, 119 (1968, t. 3) 3.

80. Daniélou, Riflessioni sul „Credo del Popolo di Dio”, 232.

81 AAS, 60 (1968) 438. - Por. Conc. (oecum. III) Ephesenum: 22. Iun. - Sept. 431, DS, $251-252$.

82 AAS, 60 (1968) 437. - Por. Symbolum „Quicumque” pseudo-Athanasianum, DS, 76; Conc. Chalcedonense, DS, 301-302.

83 AAS, 60 (1960) 442. - Por. Conc. Tridentinum: sess. XIII: Decr. de Eucharistia, DS, 1642, 1652.

84 AAS, 60 (1968) 439. - Por. Conc. Tridentinum: sess. V: Decr. de peccato orig., DS, 1513. Ciappi L., Il Credo di Paulo VI «nella remissione dei peccati», „L'Osservatore Romano", 108 (1968, nr 182) 1-2, z dnia 9 sierpnia.

85 AAS, 60 (1968) 441. - Por. przyp. 54.

86 AAS, 60 (1968) 438. - Por. przyp. 74.

87 AAS, 60 (1968) 439. - Por. przyp. 75. 
punktach Credo, doktryna II soboru watykańskiego, zwłaszcza konstytucji dogmatycznej o Kościele Lumen Gentium. 88

Fakt, że Papież uznał za stosowne przypomnieć i do wierzenia podać twierdzenia już zdefiniowane lub powszechnie jako objawione w Kościele przyjęte oznacza, iż obowiązują one nadal w Kościele jako nauka boska, choć co do niektórych szczegółów jeszcze ostatecznie nie zdefiniowana. Jasna wypowiedź papieska powinna usunąć zatem istniejącą gdzieniegdzie niepewność i wszelkie próby takiej reinterpretacji, która zmieniłaby ich sens. Uchylanie się od akceptacji tych prawd równałoby się $\mathrm{w}$ istocie rzeczy zerwaniu $\mathrm{z}$ wiarą katolicką ${ }^{89}$

Nie ulega jednak wątpliwości, że Pawłowe Credo zawiera również i takie twierdzenia, które nie osiągnęły jeszcze tej wagi doktrynalnej, która jest konieczna do definicji ex cathedra.90 Przykładowo zacytujemy tylko kilka $\mathrm{z}$ nich:

- różnorodność obrzędów liturgicznych, czy zróżnicowanie dziedzictwa teologicznego i duchowego, nie tylko nie przeszkadza jedności Kościoła, ale nawet jaśniej ją ukazuje; ${ }^{91}$

- poza Kościołem znajduje się wiele elementów uświęcenia i prawdy, które nakłaniają do jedności katolickiej; ${ }^{92}$

— istnieje nadzieja, że chrześcijanie którzy nie zażywają jeszcze pełnej wspólnoty jednego Kościoła, zjednoczą się wreszcie kiedyś $\mathrm{w}$ jedną owczarnię, pod jednym pasterzem; ${ }^{93}$

- Najświętszy Sakrament bywa przechowywany w tabernakulum, jakby w jakimś żywym sercu naszych świątyń; ${ }^{94}$

- wzrostu królestwa Bożego nie można uważać za to samo, co postęp kultury ludzkiej, czy też wiedzy lub techniki, itp. ${ }^{95}$

Wszystkie te i im podobne twierdzenia, zawierają naukę wspólną i pewną, która przyjęła się w całym Kościele. Dlatego też można ją zakwalifikować jako doktrynę katolicką. Nie jest to jednak zawsze doktryna wiary $\mathrm{w}$ ścisłym znaczeniu słowa, której treść formalnie zawiera

88 Por. AAS, 60 (1968) 438 (przyp. 15, 17); 439 (przyp. 20, 21); 440 (przyp. 25, 26, 27); 441 (przyp. 30, 31, 32, 33, 34); 442 (przyp. 35, 36); 444 (przyp. 44).

${ }^{89}$ "Il fatto che Sua Santità abbia riproposto la dottrina universalmente accettatia nella Chiesa nei termini stessi in cui essa era stata formulata nei Concili, oppure universalmente insegnata nel magistero ordinario, indica chiaramente che Egli ritiene 'che su questi punti non si possa staccare dalla dottrina e dall' insegnamento universale senza compromettere la fede cattolica", Colombo, La professione di fede del popolo di Dio, 516. - Por. Nicolau, La reciente Profesión de fe de Pablo VI, 71.

90 Nicolau, La reciente Profesión de fe Pablo VI, 72.

91 Por. AAS, 60 (1968) 441.

92 Por. tamże, 441.

93 Por. tamże, 441-442.

94 Por. tamże, 443.

95 Por. tamże, 443. 
się $\mathrm{w}$ nadprzyrodoznym Objawieniu. ${ }^{96}$ Należne jej posłuszeństwo dobrze określa konstytucja dogmatyczna o Kościele Lumen Gentium nauczając, że „zbożną uległość woli i rozumu w sposób szczególny okazywać należy autentycznemu urzędowi nauczycielskiemu Biskupa Rzymskiego nawet wtedy, gdy nie przemawia ex cathedra; trzeba mianowicie ze czcia uznawać jego najwyższy urząd nauczycielski i do orzeczeń przez niego wypowiedzianych stosować się szczerze, zgodnie z jego myślą i wola, która ujawnia się szczególnie przez charakter dokumentów, bądź przez częste podawanie tej samej nauki, bądź przez sam sposób jej wyrażania." 97

Podsumowanie tych rozważań nasuwa następujący wniosek. Wszystkie twierdzenia zawarte $\mathrm{w}$ uroczystym wyznaniu wiary zachowują ten sam stopień pewności teologicznej, jaki posiadały uprzednio, ponieważ Credo Pawła VI tylko potwierdza i umacnia ich dotychczasową pozycję doktrynalną. Bliższe sprecyzowanie stopnia pewności teologicznej każdej z jego prawd domagałoby się jednak odrębnego rozpatrzenia, zgodnie z zasadami obowiązującymi przy ustalaniu kwalifikacji teologicznej. Należy to jednakże do szczegółowego komentarza a nie do ogólnej oceny. ${ }^{98}$ Ta ocena pozwala nam tylko widzieć w Pawłowym Credo, dokument papieski o bardzo wielkim znaczeniu doktrynalnym, który zobowiązuje wiernych $\mathrm{w}$ sumieniu do pełnej akceptacji, a nie tylko do silentium obsequiosum, czyli podporządkowania czysto zewnętrznego, bez afirmacji wewnętrznej.

\section{III.}

Wśród zarzutów, które podnosi się najczęściej przeciwko nowemu Uroczystemu wyznaniu wiary, na szczególną uwagę zasługują te, które odnoszą się do sformułowań językowych, jakimi posłużył się Papież. Zarzuca się im tradycyjność, niekomunikatywność i obcość współczesnej mentalności. Problem ten, choć nie dotyczy bezpośrednio zagadnienia

96 „Todas estas proposiciones, que hemos entresacado de la Profesión de fe nos parecen doctrina común y cierta. Por esto, sin duda, y por la autoridad de quien las propone seran ciertamente recibidas en toda la Iglesia y se podrán calificar de doctrina católica; esto es, doctrina que se admite y se enseña en toda la Iglesia, aunque no se propongan como de fe. Pero no parece que sean doctrina de fe", Nicolau, La reciente Profesión de fe de Pablo VI, 72. - Por. Colombo, La professione di fede del popolo di Dio, 514-515.

97 „Hoc vero religiosum voluntatis et intellectus obsequium singulari ratione praestandum est Romani Pontificis authentico magisterio etiam cum non ex cathedra loquitur; ita nempe ut magisterium eius supremum reverenter agnoscatur, et sententiis $\mathrm{ab}$ eo prolatis sincere adhaereatur, iuxta mentem et voluntatem mani-. festam ipsius, quae se prodit praecipue sive indole documentorum, sive ex frequenti propositione eiusdem doctrinae, sive ex dicendi ratione", Conc. Vaticanum II, Constitutio dogmatica ,Lumen Gentium” de Ecclesia, w: Constitutiones. Decreta. Declarationes, 138-139.

${ }_{98}$ Por. Pozo C., El Credo del Pueblo de Dios. Comentario teológico, Madrid 1968. 
rozwoju doktryny, lecz tylko jej prezentacji w różnym, zmieniającym się z czasem i w przestrzeni kontekście cywilizacyjno-kulturowym, jest bez wątpienia bardzo ważny. Niemniej jednak podniesiona krytyka nie wydaje się być słuszna i stanowisko Pawła VI w tej sprawie jest w pełni usprawiedliwione. ${ }^{99}$ Możliwości bowiem transpozycyji nauki wiary na język zrozumiały dla mentalności człowieka żyjącego w określonej historycznie epoce są niezliczone. Papież nie chciał więc żadnej z nich szczególnie faworyzować. Dlatego prawdy nowego wyznania wiary wyraził tym językiem, w jakim zachowały się w tradycji doktrynalnej Kościoła. Jest zadaniem teologów i duszpasterzy zaprezentować je światu w języku dlań zrozumiałym. ${ }^{100} \mathrm{Na}$ tym tle, wyrażenia użyte w Credo, np. „przeistoczenie" (transsubstantio), które dzisiaj są niezrozumiałe, albo fałszywie rozumiane, nie będą wydawać się niewłaściwe. Wręcz przeciwnie! Mogą się one okazać bardzo cenne przy określaniu wzajemnego stosunku pomiędzy doktryną i jej prezentacją, chroniąc treść wiary objawionej przed zniekształceniami.101

Język Uroczystego wyznania wiary stanowi więc wytyczną dla poszukiwań filozoficzno-teologicznych w kwestiach wiary. Przy całej swej nowości i oryginalności, koniecznej w zmienionych diametralnie warunkach współczesnego świata, mają one jednak pozostać wierne prawdzie objawionej i nieskażoną podawać do wierzenia.

\section{R E S U M E}

\section{LA SIGNIFICATION THÉOLOGIQUE DE LA SOLENNELLE PROFESSION DE FOI DE PAUL VI}

C'est sur la base de l'analyse théologique de l'introduction qui précède le Credo du Pape Paul VI que l'auteur essaie de mettre en relief sa signification doctrinale.

Le seul titre la Solennelle profession de foi indique que le document pontifical possède, tant par son contenu que par sa forme littéraire, de multioles connexions avec les antiques symboles de foi. En effet, le Credo de Paul VI répète en substance

99 Tym bardziej, jeżeli ta krytyka przekracza, granice poważnego traktowania zagadnień i posługuje się zwykłymi sloganami, jak to ma np. miejsce u Régamey: „Dans cette perspective ... la pensée théologique, heureusement ouverte, ces derniers temps, est fâcheusement arrêtée par le pape et où les fidèles feront donc bien désormais de préférer leurs perplexités, voir leurs négations, aux conceptions arriérées $d u$ pape: ainsi sur la transsubstantion, l'infaillibilité pontificale, la nécessité de distinguer la croissance du Règne de Dieu et le progrès de la civilisation”, Le „Credo” du pape, „Informations catholiques internationales”, 319 (1968) 3, z dnia 1 września.

100 Daniélou, Riflessioni sul „Credo del Popolo di Dio”, 233-234.

101 Zizola, Loin de toute "passion» pour "le changement et la nouvauté", 11. 
la formule de Nicée. A cause de cela, ils jouissent, tous les deux, de la même auctorité coctrinale.

En analysant le contenu de l'introduction, il faut appeler notre attention sur les raisons qui ont occasionné la promulgation du Credo et sur l'engagement de la suprême autorité doctrinale du Pape.

En général, la promulgation du Credo a été causée par la crise de foi dans l'Eglise. C'est la Congrégation pour la doctrine de foi qui, pour la première fois, a signalé officiellement son existence, dans la lettre aux présidents des conférences épiscopales. De même, le premier Synode des évêques a consacré beaucoup de temps à cette problématique. Les évêques y ont demandé au Saint Siège d'élaborer une déclaration positive et pastorale à ce sujet. Cette crise s'est concrétisée dans le Nouveau catéchisme hollandais et est mentionnée aussi par le Pape dans l'introduction au Credo. C'est pourquoi, la profession pontificale de foi constitue une réponse autorisée aux difficultés doctrinales du temps. A présent, les conditions changées ne diminuent pas l'actualité de sa doctrine. Ça signifie que son ancienne valeur théologique est en vigueur.

Mais, la plus grande importance pour l'appréciation doctrinale du Credo réside dans tout ce que dit le Pape au sujet de l'engagement de son suprême ministère d'enseignement. D'une part, constante-t-il, sa profession de foi n'est pas une définition dogmatique dans toute l'acception du terme. Elle appartient à l'enseignement ordinaire de l'Eglise. De l'autre, elle constitue, selon Paul VI, „une parole plus solennelle". En d'autres termes, elle occupe une position particulière dans l'enseignement du magistère ordinaire du Pape.

Cela est confirmé singulièrement par le fait 'qu'on y peut découvrir toutes les conditions exigées pour la définition au sens propre, sauf l'intention pontificale de prononcer un jugement doctrinal définitif. Les voici! Le Pontife romain y remplit sa charge de pasteur et de docteur suprême de tous les chrétiens et exerce la suprême autorité apostolique. Dans son Credo il s'agit d'une doctrine de foi et de morale qui doit être tenue par l'Eglise universelle. De plus, en le prononçant le Pape fait un appel à l'assistance du Saint Esprit. Même la formule introductive est semblable, en son caratère auguste, à la formule correspondante de la bulle Ineffabilis Deus de Pie IX ainsi qu'à celle de la constitution apostolique Munificentissimus Deus de Pie XII.

Parce que la profession solennelle de foi ne veut pas être une décision ex cathedra, toutes ses affirmation, en conséquence, retiennet le même degré de qualification théologique qu'elles avaient auparavant. Quelques d'entre elles appartiennent aux dogmes formels de foi. Les autres, bien qu'elles jouissent de qualification théologique très haute, ne sont pas souvent mûres pour le jugement solennel. Or, le Pape veut seulement imposer à l'Eglise son Credo comme la doctrine catholique et obligatoire quoique, en certains cas, non finale et définitive.

Somme toute, il faut constater que la solennelle profession de foi du Pape Paul VI reste avant tout un document doctrinal et son aspect pastoral se place à l'arrière - plan. Ses formulations, bien qu'elles soient traditionnelles autorisent les théologiens à présenter au monde l'Evangile dans un langage compréhensible et actuel. 